\title{
Research of Talent Training Mode for Cooperation between Colleges and Enterprises of Professional Masters Guide by the "Excellent Program"
}

\author{
Zhihua Yuan \\ College of Equipment Engineering \\ School of Shenyang Li gong University \\ Shenyang, China \\ yuanzhihua2003@yeah.net \\ Yuhui $\mathrm{Hu}^{*}$ \\ School of Shenyang Polytechnic College \\ School of Liaoning Ordnance Industry Staff University \\ Shenyang, China \\ 1043581933@qq.com
}

\author{
Huibin Li \\ College of Equipment Engineering \\ School of Shenyang Li gong University \\ Shenyang, China \\ 1066149328@qq.com \\ Guifan Zhou \\ School of Shenyang Polytechnic College \\ School of Liaoning Ordnance Industry Staff University \\ Shenyang, China
}

\begin{abstract}
Cooperation between colleges and enterprises is an important way of cultivating applied talents of higher education. As the guidance of the "Excellent Engineering Training Program"(EETP) which organized by the Ministry of Education, establishing a personnel training mode depend on cooperation between colleges and enterprises, the talent training mode for cooperation between colleges and enterprises, and take out the corresponding operation mechanism of sustainable development. It would strive to cultivate the students' project practice ability and innovation ability, make some beneficial exploration for the excellent program and the training mode between colleges and enterprises.
\end{abstract}

Keywords-excellent program; professional master; cooperation between colleges and enterprises; talent training mode

\section{INTRODUCTION}

With the rapid growth of the national defense industry, China's defense industry demand for military personnel grows quickly, which put forward higher and more pressing requirements for the cultivation of senior weapon professionals, especially postgraduates majoring in weapons. But at present the quantity and quality of personnel in this area in our country cannot meet the needs of the development of the industry, resulting in a serious talent shortage. The lack of independent intellectual property rights, scientific nature of engineering knowledge, weakening of engineering practice are the prominent problems confronting our defense industry and technology. In recent years, educators of insight have advocated that higher education should recourse to engineering practice whether in colleges focused on cultivating engineering technical talent or that cultivating talents of engineering science.

The implementation of the Ministry of Education " Excellent Engineering Training Program" (hereinafter referred to as the "Excellent Program") is conform to the historical trend, it makes the entire depth of the industries and enterprises to participate in the master of professional personnel training process, during the period of school, students accepted the education and training of enterprise, to strengthen the students' engineering practice ability and innovation ability training [1].

\section{The Necessity OF CONStRUCting TALENT TRAining MODE FOR COOPERATION BETWEEN COLLEGES AND ENTERPRISES}

Against the background of "Excellent Program " talent training mode for cooperation between colleges and enterprises is one kind of mode which giving priority to "enterprise learning" , and make the engineering application ability as the main line, using two kinds of different education environment and education resource of schools and enterprises[2].

In order to make the initiative meet the needs of the national defense industry and make better contribution to the country and enterprises. That is the top priority to build the distribution and structure optimization, various types of modern higher engineering education system, reform of the graduate engineering education personnel training mode, and also the innovation of colleges and industries joint personnel training mechanism.

About the form of cooperation between colleges and enterprises, there is a fund project "excellent engineering training program under the background of co-operative research and practice" which is professor Qi Xie applied in our country. The papers which teacher Lihui Fan published, it point out that the practice of the mode for cooperation between colleges and enterprises, they all think from the perspective of school, and it should take various measures to strengthen students' practical ability training, through the mode for cooperation between colleges and enterprises to cultivate the college students. 
In foreign countries, the main content is the study of cultivating talents and work together with penetrate, that is, learning in the work, work with learning. The main form of the mode are "Sandwich" in England and "Institute of Engineers" mode in France, "Cooperative Education" mode in America, etc., and the world association for cooperative education advocates of "Combining Learning With Work". The main function is improve the students' professional practice, so when students graduate from the school into a career that they would have certain work experience and experiences, also a certain social adaptation ability.

\section{A. Talent Training Mode of the Cooperation between Colleges and Enterprises can Realize School, Enterprises and Master's Tripartite Win-Win Situation}

The colleges implement to open the door, and grasp the market and subject frontier education timely. The teaching effect improved obviously, the enterprises train a batch of the elite team that loving the enterprise, which can realize the seamless joint between the using of talent [3]. And promote the development of enterprises, students also can improve the comprehensive quality and engineering practice ability, cultivate teamwork spirit, and enhance competitiveness, expand career development space.

\section{B. Cultivation of Talents of the Cooperation between Colleges and Enterprises is a New Measure of Deepening the Reform of Education Teaching}

Giving priority to the enterprise practice study way and the joint of enterprise orientation training professional master's degree, it is the location of whether weapon of applied professional master's degree can meet the demand of enterprise, important measures of teaching reform and deepening innovation education.

\section{Enterprise Practice is the Key to the Implementation of Talent Training Cooperation between Colleges and Enterprises Personnel Training}

"Excellent Program" is the significant steps of the ministry of education to promote China from the engineering education country towards engineering education power. There is 1 year for professional master's professional practice, and it takes the mode of professional practice and thesis integration. Professional practice is the main link of the joint training.

\section{THE OPERATION KEY POINTS TO THE PROFESSIONAL MASTER OF TALENT TRAINING MODE FOR COOPERATION BETWEEN COLLEGES AND ENTERPRISES}

\section{A. Set up the Cooperation Concept of Active Service for the Enterprise}

"Excellent Program" and the cultivation of professional master's requirements need cooperation between colleges and enterprises and require the enterprises to participate in the training process of students' engineering practice ability and innovation ability when they are in school. But some of the cooperation between colleges and enterprise confined to the surface form, it just put students into the enterprise practice cognition, the enterprise did not truly benefit from the program, and some students choose the location and scale of the enterprise, lead to the students lost their enthusiasm, it affects the enterprise to participate in the enthusiasm more or less. In order to promote the joint cultivation between colleges and enterprises sustainable development, we must take the initiative to set up the concept of service for the enterprise, and make the resources of teachers to serve the enterprise, the school master's project or participate in the project, are direct from the enterprise needs. It should meet the needs of enterprise talent pool, and the needs of the labor force structure, to improve the enterprise's responsibility and initiative to participate in the " Excellent Program "and the talent cultivation.

\section{B. Construct a High Level Team of Engineering Education}

Practice teaching in colleges and universities is an important part of the whole teaching activity for the engineering. The practice innovation ability training is the important content of quality education. War Industry Specialty locates to the training of "wide scope, compound" "senior applied talents, to cultivate the high-level talents who have the ability to solve practical engineering technology research and development. The practice teaching has an irreplaceable role in cultivating students' innovation consciousness and practical ability, and the ability to analyze and solve problems. So, strengthen practice teaching in the school, strengthen the cultivation of students during the period of school practice ability, especially the cultivation of students' practice ability and innovation consciousness [4-6]. Build specialty characteristics, students need to have strong ability of practice. High demands on students' practical ability, students on the basis of fully understanding and practice to better master the knowledge. We put forward the combination of universityenterprise cooperation senior applied talents training mode.

We encourage college teachers to study in enterprise and in a planned way to improve their ability of engineering practice, at the same time, we encourage mentors in enterprise to study in university and improve the level of theory teaching, teaching method, and promote talent training cooperation between colleges and enterprises quality enhancement. Therefore, Shenyang $\mathrm{Li}$ gong University makes the "Measures for Teachers' Implementation of Enterprise Engineering Experience in University" and "Measures for the Implementation of Enterprise Part-time Teachers", it safeguard the university-enterprise joint personnel training quality from the institution. New pattern of joint cultivated is determined. Postgraduate training double- mode system is established.

\section{Innovate the Teaching Organization Mode}

In the whole teaching process to get the integration of the teaching practice and the theoretical teaching. And in the set of teaching content, from the students' time and network space mining potential at ordinary times, especially on the basis of new concept weapon experiment content and guide, greatly improving the students' learning interest and subjective initiative of the transfer. Practice teaching content and theory teaching content integration and crisscross, strive to achieve the best effect of teaching. 
In order to cultivate students' innovation consciousness and practice ability, the school combined with outstanding engineers' plan, on the basis of engineering practice education, actively encourages college students to participate in the innovation business plan. Let college students to participate in scientific research project, publish research papers, and the school teaching reform project, and to participate in the college students competition at all levels. Encourage students to do some topics which like ordering the list during graduation design, it is based on students' interest in the enterprise, according to enterprise actual problem, carries on the exploratory study.

Talent training mode for cooperation between colleges and enterprises that based on "Excellent Program" makes enterprise learning as the important way, so the theory lesson course combine with the practical background and the reconstruction of the teaching system is imperative. We study master's innovation education teaching mode, based on the project type of learning methods, based on the exploration of learning, and based on problem learning approach too. We should further expand the teaching organization mode. At the same time we should establish and improve the system of credits and grades of evaluating

\section{IMPLEMENTATION Plan FOR THE PROFESSIONAL MASTER'S JOINT TRAINING MODE}

For weapons full-time professional master's degree students' training characteristics, combined with the plan of professional graduate program and Excellent Engineering Training Program, combined with the characteristics of military enterprise, we formulate appropriate venture of cooperation between colleges and enterprises, and set up alliance between the equality and mutual benefit, and adhere to the way of getting out and entering in to the study and research the similar professional alliance mode between colleges and enterprises at home and abroad, we make a appropriate new model for our school, and study the implementation of the professional master graduate student of talent training cooperation between colleges and enterprises mechanism and the implementation rules. Based on one year of professional practice and thesis requirement, we make the mechanism of teaching quality supervision, guarantee and feedback.

To explore and study the scheme of implementation, we can set out from the following aspects:

- Establish the principle of co-cultivating talents, joint management, achievements-sharing, responsibilitysharing.

- Set up the mechanism of sustainable development, the cultivated plan should build relationship with enterprises on equal terms and mutual benefit, adhere to complementation of human resources and facility resources, and must be adopt the idea of taking the initiative to serve enterprises.

- Using the University-Enterprise mutual engagement system, involving enterprises in the whole process of postgraduate trainings. Enterprises deliver lectures to students and universities go to enterprise workshops, developing curricula together with enterprises, with the latter participating in postgraduates' professional practice and thesis writing.

- Study teaching and course system for professional masters with enterprises together, and adopt the teaching organization model through the whole training process which the corporate senior tutor always runs.

- Set up practice bases both in and out of school; build a training mechanism based on the corporate needs and a joint training system of no-slot joint with an "order" form.

- Establish a sound joint research group of curriculum and instruction and a joint workgroup of student management, which involves enterprises, education committee of professional degree, "Excellence Program" committee and universities, and to improve the comprehensive protection mechanism.

- Develop the system of regular surveys in workshop, quality supervision and evaluation feedback.

\section{EXPLORATION OF THE OPERATING MECHANISM FOR THE MODE OF UNIVERSITY-ENTERPRISE JOINT TRAINING OF PROFESSIONAL MASTERS}

The mode of university-enterprise joint training of professional masters, under the background of "Excellence Program" and with practicing in enterprises as the main supporting method, is a completely brand-new approach to talent cultivation. The main contents of the operation mechanism are as follows: enterprises and universities work together to formulate postgraduate training plans, programs of students' learning by practicing in enterprises and the former's standard and the latter's evaluation system and its management method; to establish "Project Teaching Team" to develop new courses, compile new textbooks. Co-teach students and provides guidance for students' project practice; to research on education and teaching reform and found the project practice teaching center. A new personnel training mode with distinctive professional characteristics, a complete training system, sound evaluation system and perfect supervision mechanism will be established after researches and practice, with its aim to improve students' abilities of project practice and innovation and achieve the goal of "excellence program" ultimately

\section{REFORM OF TEACHING METHODS AND MEANS}

Build the professional characteristics, more attention should be paid on actual requirement in teaching content, integrating relevant courses together, strengthening the basic curriculum of the artillery manufacturing technology, without any increase in the number of courses, to let the students get more artillery design and manufacture of professional knowledge.

To strengthen the practice teaching link in teaching methods, take active "in the laboratory and enterprise field theory teaching and practice teaching integration" teaching model, according to the different kinds of courses, because of 
the condition to innovate the teaching methods, course boundary between the laboratory and the classroom, the classroom is located in the laboratory, combine theory with practice, effectively help the students understand the content of manufacturing technology, strengthen the cultivation of the student beginning ability, to improve students' ability for design and manufacture of artillery.

Through the practice, the students' learning ability and the ability to solve practical problems would have greatly been improved.

By designed, especially for curriculum design in view of the enterprise actual demand and the range of enterprise practice, to make the students have the direct contact to the needs of the enterprises, through training, to be able to use knowledge to solve the problem of enterprise's actual. Both consolidate the knowledge learn, and improve the students' learning enthusiasm.

\section{CONCLUSION}

In order to adapt to the defense industry demand for launching weapon engineering senior talents, according to the talent training mode for cooperation between colleges and enterprises of professional masters' guide by the "Excellent
Program", gradually formed an opening in the engineering practice talents cultivation system

\section{REFERENCES.}

[1] Qi Xie, Yi Deng, Research of Talent Training Mode For Cooperation Between Colleges and Enterprises in Implementing "Excellent Program"[J]. Journal of Hunan Institute of Engineering, 2013(1) : 106 -108 . (in Chinese)

[2] Xiping Liu, Zhijun Zhou, Study of Cooperative Pattern Between College and Enterprise for Applied Undergraduate Colleges $[\mathrm{J}]$. Journal of Jixi University, 2011(12): 16 -17. (in Chinese)

[3] Hong Ye, Pei Chen, Zhiqiang Liu, Meijing Ji, The Mode of Cooperation Between Colleges and Enterprises Talent Training [J]. Continue Education Research, 2009( 9) : 173 - 174. (in Chinese)

[4] Qingsong Liu, Taibin Cao, Suxiang Qian, Research and Practice of Training Innovative Talents "Industry-University-Institute" Cooperation [J].China Electric Power Education, 2012, (22):25-26, 34. (in Chinese)

[5] Zhiling Liao, Xianxing Liu, Guohai Liu, Based on the Characteristics of Electrical Engineering and Its Automation National Professional High Quality Innovative Talents Cultivation [J]. China Electric Power Education, 2011, (1):12-13. (in Chinese)

[6] Yongsheng Ding, Zhijie Wang, Kuangrong Hao, Peide Sun, "Driven" Engineering Automation Innovative Talent Training System Study [J]. China Electric Power Education, 2012, (34):30-31. (in Chinese) 